\title{
REKONSTRUKSI STEREOTIP NEGATIF ETNIK MELAYU
}

\author{
Alfarabi $^{1}$, Anter Venus ${ }^{2}$, Nuryah Asri Syafirah ${ }^{3}$, Noor Efni Salam ${ }^{4}$ \\ ${ }^{1}$ Universitas Bengkulu, ${ }^{2}$ Universitas Padjajaran, ${ }^{3}$ Universitas Padjajaran, ${ }^{4}$ Universitas Riau
}

\begin{abstract}
ABSTRAK
Stereotip negatif yang dilekatkan pada etnik Melayu dijadikan ukuran untuk menilai anggota etnik tersebut. Datangnya era reformasi yang memberi ruang pada etnik lokal untuk menduduki jabatan-jabatan strategis membuat etnik Melayu berkesempatan untuk merekonstruksi stereotip yang melekat pada diri mereka. Penelitian mengkaji bagaimana tokoh Melayu mengcounter stereotip negatif sekaligus merekonstruksi stereotip tersebut menjadi sesuatu yang positif bagi etnik. Penelitian ini menggunakan pendekatan kualitatif dengan studi fenomenologi. Pengumpulan data lapangan menggunakan wawancara mendalam dan observasi. Hasil penelitian ini memberitahukan bahwa stereotip negatif pada etnik Melayu merupakan bentuk ketidaktahuan pendatang terhadap Orang Melayu. Upaya meng-counter stereotip negatif yang dilekatkan pada etnik Melayu dilakukan untuk meningkatkan status etnik yang lebih positif. Kondisi tersebut menjadi penting karena pascareformasi etnik Melayu memiliki kesempatan yang besar untuk menduduki jabatanjabatan strategis di Pekanbaru Riau.
\end{abstract}

Kata-kata Kunci: Stereotip, Melayu, Etnik, Reformasi, Pendatang

\section{THE MELAYU ETHNIC GROUP'S RECONSTRUCTION OF NEGATIVE STEREOTYPES}

\begin{abstract}
Negative stereotypes attached to Melayu ethnic groups are used to assess members of the groups. The reform era gives spaces for the local ethnic groups to carry out certain strategic positions in the local government or in the community. It gives them opportunity to reconstruct stereotypes attached to them. This research is to describe how the leaders of Melayu face the negative stereotypes and change them into positive ones. A qualitative approach and phenomenology research design are the most suitable research methods to find the research objectives. Data were collected through in depth interviews and observation. It was found out that negative stereotypes are the incomprehensibility of immigrants to Melayu ethnic groups. Their efforts to face up negative stereotypes are implemented to boost up the positive status of the groups. This is very important because Melayu ethnic groups have been given large opportunities to hold strategic positions in local government of Pekanbaru Riau.
\end{abstract}

Keywords: Stereotype, Melayu, Ethnic, Reform, Immigrants

Korespondensi: Dr. Alfarabi, S.Sos., MA. Universitas Bengkulu. Jl. WR Supratman, Kandang Limun, Muara Bangka Hulu, Kota Bengkulu, Bengkulu 38371. Email: alfarabi@unib.ac.id 


\section{PENDAHULUAN}

Manusia sebagai makhluk sosial harus selalu hidup bersama. Manusia selalu hidup bersama secara kolektif dalam kesatuan-kesatuan sosial yang besar maupun kecil. Dalam kesatuan sosial inilah manusia hidup saling berinteraksi, bekerja sama, dan bertukar pengetahuan untuk dapat mencapai tujuan hidupnya (Muchtar, Koswara, Setiaman, 2016:113)

Identitas etnik tidak hanya didapat secara subyektif dengan cara mendefinisikan sendiri identitas mereka. Dalam realitas identitas etnik terkadang didapat dari pengidentifikasian yang dilakukan oleh orang lain di luar etnik. Pada kehidupan sehari-hari dikenal dengan nama stereotip. Penyematan stereotip negatif pada suatu etnik pada beberapa kasus justru menjadi ukuran untuk menilai identitas etnik tersebut. Stereotip menurut Matsumoto adalah generalisasi kesan yang kita miliki mengenai seseorang terutama karakter psikologis atau sifat kepribadian (Lampe \& Anriani, 2017, p. 21). Hal yang sama terjadi pada etnik Melayu yang juga didefinisikan dari stereotip yang hidup di tengah masyarakat Pekanbaru. Etnik Melayu dilekatkan stereotip negatif yang dianggap sebagai bagian dari karakteristik Orang Melayu. Dalam kehidupan sehari-hari etnik Melayu dilekatkan dengan stereotip pemalas dan menjauhi konflik (Hasbullah dan Jamaluddin, 2013, p. 1; Suciati \& Agung, 2017, p. 105). Beberapa penelitian bahkan memperkuat stereotip pemalas dengan menyebutkan bahwa mental Melayu tersebut merupakan tantangan yang harus diselesaikan oleh Orang Melayu (Hasbullah dan Jamaluddin, 2013, p. 11).

Melayu sebagai etnik lokal di Riau merupakan kelompok masyarakat yang mengalami tekanan dan penindasan di era pemerintahan Orde Baru sehingga tidak dapat mengembangkan identitasnya (Andriana, 2011, p. 114; Haboddin, 2012, p. 126; Syafuan Rozi, 2009, p. 82). Runtuhnya pemerintahan Orde Baru memberikan sebuah semangat baru bagi masyarakat lokal untuk bergerak dan memperkuat kedirian kultural mereka sebagai senjata untuk menuntut hak-hak pribumi (Setiawan, Tallapessy, \& Subaharianto, 2015, p. 11). Di era reformasi di mana otonomi daerah dan sistem politik pemilihan langsung memberikan ruang yang luas kepada etnik lokal untuk menduduki jabatan strategis maka stereotip negatif dapat menghambat pencapaian tersebut.

Penelitian ini mencoba mengkaji bagaimana etnik Melayu menggunakan peluang di era pascareformasi untuk menampilkan identitas etnik di daerahnya sendiri. Wilayah penelitian berada di Pekanbaru Riau. Pemilihan kota Pekanbaru dikarenakan jumlah etnik Melayu di kota ini justru tidak mayoritas. Data BPS terakhir yang dikeluarkan tentang perbandingan etnik di Pekanbaru pada tahun 2010 memberitahukan bahwa etnik Melayu hanya berjumlah 26\%, jauh di bawah etnik Minang yang berjumlah 37\%, sisanya adalah etnik Jawa, Batak, Tionghoa dan etnik lainnya (BPS, 2015). Sebagai etnik lokal maka Melayu memiliki kepentingan untuk menaikkan daya tawar etniknya dalam otonomi daerah dan sistem politik pemilihan langsung yang bermuara 
pada kepemimpinan daerah. Upaya meningkatkan daya tawar etnik tersebut salahsatunya akan dilihat dari counter terhadap stereotip negatip yang dilekatkan pada etnik Melayu.

\section{METODE PENELITIAN}

Peneliti menggunakan pendekatan kualitatif untuk mengeksplorasi stereotip tentang etnik Melayu dan upaya counter stereotip yang dilakukan partisipan penelitian. Peneliti memilih studi fenomenologi untuk mereduksi pengalaman individu pada stereotip negatif Melayu menjadi deskripsi tentang esensi atau intisari universal (Creswell, 2014, p. 105). Data lapangan dikumpulkan dengan wawancara mendalam, observasi dan studi pustaka. Informan penelitian dipilih dari kalangan tokoh masyarakat berdasarkan rekomendasi dari partisipan kunci yang telah dipilih sebelumnya. Partisipan selanjutnya dipilih atas rekomendasi partisipan sebelumnya.

\section{HASIL DAN PEMBAHASAN}

Peneliti mengkaji stereotip terhadap Orang Melayu yang hidup di tengah masyarakat untuk melihat gambaran bagaimana masyarakat Melayu memandang dirinya sendiri dan memandang pendatang yang hidup bersama mereka. Dalam sudut pandang lain maka stereotip negatif terhadap masyarakat Melayu juga memberitahukan bagaimana cara pandang pendatang di Pekanbaru melihat etnik Melayu. Peneliti melakukan juga wawancara dengan etnik pendatang di Pekanbaru untuk mempertegas stereotip negatif apa saja yang dilekatkan pada etnik Melayu melalui berbagai karakter dalam cerita-cerita yang berkembang di masyarakat. Karakter-karakter yang dipercaya sebagai karakter Orang Melayu di kehidupan nyata. Dari hasil wawancara awal yang dilakukan terdapat beberapa istilah yang dilekatkan sebagai stereotip negative Orang Melayu, yaitu 'Orang Melayu pemalas', 'Orang Melayu tidak mau bekerja keras', dan 'Orang Melayu menghindari konflik'. Penyematan tersebut tidak hanya sekedar pelabelan biasa karena memiliki dampak pada keberadaan Orang Melayu dalam kehidupan sehari-hari. Hasil wawancara memberitahukan bahwa stereotip juga tidak hanya sekedar menunjukan citra positif dan negatif tetapi juga mempengaruhi posisi Orang Melayu ketika berhadapan dengan etnik lain di Pekanbaru.

Apabila dihubungkan dengan perubahan yang terjadi di era reformasi di mana terdapat pemberlakukan kebijakan otonomi daerah dan sistem pemilihan langsung maka kebutuhan identitas etnik yang positif menjadi strategis di era pascareformasi. Konsekuensi dari penggunaan identitas etnik dalam politik maka perbandingan etnik menjadi lumrah dilakukan. Masing-masing etnik tentu saja ingin menampilkan citra positif untuk setara bahkan lebih tinggi dari etnik lain. Etnik yang dilekati identitas negatif berusaha sekuat tenaga untuk menghapus stereotip negatif agar citra etnik menjadi lebih baik. Situasi yang sama dilakukan oleh Orang Melayu pascareformasi yang berusaha merekonstruksi stereotip etniknya. Salahsatunya dengan meluruskan stereotip negatif yang melekat dalam karakter Orang Melayu Riau. 
Gambaran stereotip negatif yang dilekatkan pada Orang Melayu dan upaya meluruskannya diuraikan dalam subbab di bawah ini.

\section{Orang Melayu Itu Pemalas dan Counter}

\section{Terhadap Stereotip Negatif Tersebut}

Stereotip pemalas, tidak suka bekerja keras, suka bersenang-senang dan suka menghabiskan waktu dengan mengobrol yang siasia disematkan kepada Orang Melayu secara umum di Riau termasuk di Pekanbaru. Anggapan tersebut tidak hanya disematkan oleh pendatang yang ada di Riau, tetapi juga diakui oleh sebagaian Orang Melayu itu sendiri. Stereotip ini lahir dari perilaku Orang Melayu yang suka berkumpul di warung kopi dan mengobrol menghabiskan waktu sepanjang hari. Istilah untuk mengambarkan aktifitas mengobrol di warung kopi tersebut adalah 'berbual-bual'. Sebuah istilah untuk mengambarkan bahwa obrolan yang dilakukan tidaklah penting dan sekedar menghabiskan waktu.

Aktifitas Orang Melayu tersebut menjadi kontras karena pada waktu yang bersamaan orang lain sedang sibuk bekerja keras. Orang Melayu dianggap berleha-leha. Aktifitas berleha-leha tersebut menjadi alasan munculnya anggapan bahwa Orang Melayu itu pemalas.

Anggapan berikutnya pada Orang Melayu yang hampir sama dengan stereotip pemalas adalah 'Orang Melayu tidak mau bekerja keras'. Stereotip ini untuk menggambarkan bahwa dalam bekerja Orang Melayu hanya sekedarnya saja. Peneliti mendapatkan pengertian kata 'sekedarnya saja' melalui contoh bahwa Orang Melayu itu jika sudah mendapat sedikit, cukup untuk makan, maka akan menghentikan pekerjaan karena lebih suka mengobrol di lepau kopi. Tidak ada upaya untuk meningkatkan pendapatan. Pascareformasi stereotip Orang Melayu tidak suka bekerja keras dihubungkan dengan situasi Provinsi Riau yang sedang giat membangun dan membutuhkan banyak tenaga kerja. Kesiapan etnik pendatang untuk bekerja di segala bidang dikontraskan dengan Orang Melayu yang hanya memilih bidang-bidang tertentu. Pekerjaan yang paling diminati oleh Orang Melayu adalah Pegawai Negeri Sipil (PNS). Menurut partisipan, pilihan PNS diambil karena kerjanya lebih santai, banyak liburnya dan bisa pulang lebih cepat. Pilihan menjadi PNS juga dianggap dekat dengan aktifitas kehidupan istana seperti era kerajaan Melayu. PNS dapat diibaratkan pegawai-pegawai kerajaan di era modern.

"Pekerjaan menjadi PNS cenderung santai dan tidak banyak aktifitas. Karakter pekerjaan tersebut sesuai dengan karakter Orang Melayu yang dianggap pemalas dan tidak suka bekerja keras" (Ahmad, September, 2017).

Konsekuensi dari pilihan pekerjaan yang hanya terkonsentrasi pada PNS tersebut membuat bidang pekerjaan-pekerjaan lain seperti pedagang, buruh, petani yang membutuhkan banyak tenaga dan waktu diambil oleh pendatang dari etnik lain. Pilihan bidang pekerjaan tersebut melatarbelakangi stereotip bahwa Orang Melayu itu tidak mau bekerja keras.

Counter atas stereotip tentang karakter Orang Melayu tersebut peneliti dapatkan dari partisipan penelitian yang melihat adanya cara 
pandang yang keliru terhadap masyarakat Melayu.

Menurut para partisipan, stereotip negatif terhadap karakter Orang Melayu kebanyakan karena orang lain tidak memahami latar kehidupan Orang Melayu. Ketidakpahaman tersebut membuat pendatang (dan termasuk juga Orang Melayu sendiri) memandang masyarakat Melayu itu pemalas dan tidak suka bekerja keras. Partisipan penelitian menceritakan bagaimana alam Melayu telah mendidik Orang Melayu seperti sekarang ini (Darmawi, Agustus 2017).

"Orang Melayu itu bukan pemalas, tapi cukup dengan yang telah didapat. Orang Melayu tidak rakus dalam mengeksploitasi alam (Darmawi, September 2017).

Pendapat Darmawi diperkuat oleh Sabli yang melihat sumber daya alam Riau yang subur membedakan cara Orang Melayu dalam menikmati hasil alam.

"Alam Melayu sangat kaya, tanahnya
subur dan sungainya dipenuhi banyak
ikan. Kesuburan tanah Melayu
membuat Orang Melayu cukup
menanam padi beberapa petak,
menanam sayur di sekitar rumah,
menjala ikan di sungai untuk memenuhi
kebutuhan hidup sehari-hari. Menanak
nasi, memasak sayur ditambah hasil
tangkapan ikan hari itu sudah cukup
bagi Orang Melayu" (Sabli, Agustus
2017).

Stereotip bahwa Orang Melayu itu pemalas dan tidak suka berkerja keras ditolak karena bertentangan dengan ajaran Islam. Melayu yang identik dengan Islam tidak akan mungkin tindakan dan perilakunya bertentangan dengan nilai-nilai keislaman. Cara Orang Melayu dalam menikmati kekayaan alam Riau dianggap sebagai wujud dari nilai-nilai Islam itu sendiri.

"Itulah bedanya Orang Melayu. Bagi Orang Melayu rezeki itu bukan banyaknya, tapi berkahnya. Setelah cukup ia berhenti. Beribadahlah ia lagi. Tidak seperti orang lain yang demi rezeki tahan melakukan apapun, termasuk meninggalkan ibadah" (Hamidy, September 2017).

Makna rezeki menjadi tolak ukur lain bagi Orang Melayu untuk mengatakan bahwa aktifitas mereka tidak hanya mengejar dunia tetapi juga akherat. Orang Melayu mencari rezeki sekedarnya saja karena bagi mereka urusan yang lebih penting adalah beribadah. Konstruksi bahwa Melayu itu adalah Islam sama artinya dengan menyatakan bahwa stereotype Orang Melayu itu pemalas dan tidak suka bekerjakeras adalah sebuah kesalahan karena hal tersebut bertentangan dengan ajaran Islam.

\section{Orang Melayu itu Menjauhi Konflik dan Counter terhadap Stereotip Tersebut \\ Orang Melayu dianggap memiliki karakter} menjauhi konflik. Karakter Orang Melayu yang dianggap menjauhi konflik tersebut membuat sesuatu yang membutuhkan tindakan langsung tidak dapat diselesaikan secara cepat. Hal ini diungkapkan Effendi (September, 2017) tentang tokoh-tokoh Riau yang selalu bicara tentang kesalahan di Riau namun ketika diminta untuk turun atau tandatangan pernyataan sikap ada saja alasan untuk tidak ikut. Ada perasaan sungkan kalau harus berhadap-hadapan secara langsung dalam konflik. Ketidaksetujuan terhadap sesuatu 
lebih banyak dilakukan dengan 'gumam'. Sebuah istilah untuk menggambarkan kebiasaan Orang Melayu yang menyatakan ketidaksetujuan namun tidak langsung pada orang yang bersangkutan. Karakter menjauhi konflik dianggap merugikan apabila terjadi perundingan karena cenderung akan kalah. Inilah yang menurut Fakhrudin (Juli 2017) salah satu faktor banyak lahan Orang Melayu berpindah tangan.

"Sebagaimana kebanyakan Orang
Melayu, lahan yang dimiliki biasanya
tidak digarap sepenuhnya. Terkadang
dibiarkan terlantar dan ditumbuhi
semak atau hutan. Pendatang yang
melihat lahan terlantar cenderung
berani untuk menggarap karena ada
anggapan bahwa Orang Melayu itu baik
dan tidak akan terlalu marah jika
mengetahui hal tersebut. Selama Orang
Melayu tidak menyadari maka
keuntungan lahan tersebut dikelola oleh
pendatang. Ketika Orang Melayu
mengetahui hal tersebut dan meminta
lahannya dikembalikan, pendatang
yang mengelola minta ganti rugi karena
lahan yang diolahnya telah
menghasilkan. Orang Melayu yang
tidak mau mengganti rugi lebih memilih
membagi dua lahan tersebut. Separuh
untuk pendatang yang menggarap,
separuh lagi untuk dia sendiri"
(Fakhrudin, Juli 2017)

Cerita dengan tema yang sama disampaikan juga oleh Hermanto (Agustus 2017) yang menilai ada kesadaran dari pendatang untuk berani menggarap lahan Orang Melayu karena menyadari Orang Melayu itu baik dan caranya menyelesaikan permasalahan selalu tidak menghakimi. Apabila terjadi konflik dalam kepemilikan lahan maka solusi yang diambil Orang Melayu adalah membagi dua lahannya dengan pendatang. Pola tersebut melahirkan anggapan bahwa karena sikapnya yang baik tersebut maka Orang Melayu punya kelemahan jika diajak berunding. Apabila Orang Melayu diajak berunding maka akan kalah.

Bantahan tentang kesalahan cara memahami karakter Orang Melayu disampaikan oleh Hamidy (November 2017) yang menyatakan bahwa ada yang salah dalam memahami ungkapan Orang Melayu menghindari konflik. Menurut Hamidy yang betul itu bukan konflik tapi perselisihan. Orang Melayu itu menghindari perselisihan/pertikaian karena sedapat mungkin tidak menyinggung perasaan orang lain. Menjaga perasaan orang lain merupakan ragam emosi Orang Melayu yang menghindari silang sengketa. Dengan menghindari perselisihan maka terbuka jalan perundingan agar satu dengan yang lain sampai pada kesepakatan untuk membuat perdamaian. Menghindari perselisihan adalah jalan yang diambil untuk membuka langkah perundingan. Dengan demikian ragam emosi Orang Melayu tersebut bukan menghindari konflik tapi selalu berusaha untuk menyelesaikan masalah yang tengah terjadi.

Ketika Orang Melayu berhadapan dengan konflik maka sedapat mungkin diselesaikan dengan cara menyenangkan kedua belah pihak. Tidak ada yang kehilangan muka adalah tujuan penyelesaian konflik. Dalam kehidupan sehari-hari konflik sedapat mungkin akan dihindari. Partisipan penelitian (Ahmad, Juli 2017; Hermanto, September 2017) mengatakan karakter Melayu yang menjauhi konflik merupakan gambaran bahwa Orang Melayu itu cinta damai. Proses 
penyelesaian dengan cara memenuhi kebutuhan orang-orang yang berkonflik adalah jalan bagaimana kedamaian itu bisa tercipta di tanah Melayu Riau.

Orang Melayu Itu Mudah Dimanfaatkan dan Munculnya Kewaspadaan terhadap Pendatang

Orang Melayu dikenal sebagai etnik yang terbuka, baik, dan merangkul kepada semua pendatang. Keterbukaan Orang Melayu terlihat dalam menyambut pendatang yang ingin mencari hidup di Pekanbaru. Dalam berbagai cerita yang disampaikan partisipan, kebaikan Orang Melayu dalam menyambut pendatang ditunjukan dalam bentuk memberikan izin tinggal atau membuka usaha di lahan yang mereka miliki.

"Orang Melayu itu jika ingin dibilang baik maka baiknya itu betul-betul baik. Ibarat tamu datang tidak hanya dipersilahkan ke teras, dipersilahkan juga ke ruang keluarga, ke kamar, ke dapur..." (Hermanto, September 2017).

Ungkapan Budi Hermanto di atas disampaikan juga oleh partisipan lain (Sabli, Agustus 2017; Darmawi, Juli 2017; Nizamil, April 2017; Fakhruddin, Agustus 2017) untuk menggambarkan bagaimana kebaikan Orang Melayu terhadap pendatang. Stereotip positif bahwa Orang Melayu itu baik ternyata tidak otomatis dimaknai secara positif oleh Orang Melayu itu sendiri. Dalam konteks kekinian, kebaikan dari hati Orang Melayu tersebut sering dimanfaatkan oleh pendatang untuk mengeruk keuntungan, bahkan merebut hak milik Orang
Melayu. Lahan, hutan dan minyak bumi telah banyak dimiliki oleh pendatang yang justru mereka sambut dengan tangan terbuka tersebut. Kondisi inilah yang melatarbelakangi munculnya anggapan bahwa Orang Melayu itu bodoh dan mudah dimanfaatkan. Orang Melayu dianggap tidak sadar bahwa zaman sudah berubah di mana tidak semua pendatang yang datang ke Riau itu baik. Orang Melayu diminta waspada terhadap pendatang yang mencari keuntungan dari kebaikan Orang Melayu.

"Orang Melayu harus menyadari bahwa zaman telah berubah. Dahulu mungkin manusia masih sedikit yang jahat. Namun saat ini sudah seharusnya ada kewaspadaan terhadap kehadiran orang asing di sekitar kita. Sebab tidak semuanya baik. Kewaspadaan tidak harus mengubah sifat terbuka Orang Melayu. hanya berhati-hati saja". (Sabli, Juli 2017)

Karakter Orang Melayu yang terbuka dan merangkul pendatang menjadi stereotip positif ketika ditempatkan pada bagaimana Orang Melayu menyambut tamu. Penilaian menjadi negatif ketika karakter Orang Melayu yang terbuka dan merangkul tersebut dianggap karakter yang mudah dimanfaatkan oleh orang lain yang mencari keuntungan dari keluguan Orang Melayu.

\section{Rekonstruksi Makna Stereotip Merupakan Upaya}

\section{Menampilkan Wajah Baru Melayu}

Rekonstruksi stereotip etnik Melayu dilakukan untuk meluruskan pandangan yang sudah terlanjur melekat pada masyarakat. Stereotip negatif terhadap masyarakat Melayu dianggap merugikan karena melemahkan posisi Orang Melayu dihadapan pendatang. Rekonstruksi 
dilakukan dengan cara meluruskan pemahaman terhadap karakter Orang Melayu yang salah dimengerti selama ini. Stereotip negatif terhadap masyarakat Melayu berdampak buruk karena menempatkan etnik Melayu menjadi tidak kompetitif dengan etnik lain di Riau. Salah satu contohnya adalah pada saat penerimaan pegawai di perusahaan, partisipan penelitian meyakini bahwa banyak perusahaan melakukan diskriminasi karena stereotip negatif yang dilekatkan pada Orang Melayu. Dalam penerimaan pegawai, perusahaan swasta dan asing di Riau cenderung untuk mengambil pekerja dari luar Riau karena dianggap lebih mau bekerja keras dan cenderung penurut.

"Buktinya anak-anak Riau tidak bisa masuk ke perusahaan-perusahaan minyak. Yaa terutama perusahaan Caltex ya. Chevron. Anak-anak daerah tidak dapat perhatian, padahal perjanjian Sultan Siak dengan Caltex dulu tu ada anak daerah itu 50\% kok. Dituliskan buku itu ada 50\%, 50\% kalau enggak salah saya itu. Di sana cuma ada alumni-alumni. alumni-alumni ITB yang banyak disana" (Budi Hermanto, September 2017).

Budi Hermanto juga menilai kebijakan perusahaan tersebut turut menjadi faktor banyaknya pendatang di Riau secara umum, termasuk di Pekanbaru. Keterpinggiran masyarakat Melayu dalam perekrutan pegawai perusahaan sudah menjadi wacana umum yang disadari baik oleh pendatang maupun pada masyarakat Melayu sendiri. Redefinisi dilakukan selain untuk mengklarifikasi karakter masyarakat Melayu yang sebenarnya, juga dimaksudkan untuk mereposisi kedudukan masyarakat Melayu dalam struktur sosial di Riau, khususnya Pekanbaru.
Rekonstruksi yang

dilakukan menitikberatkan penjelasan bahwa karakter Orang Melayu yang ditunjukkan selama ini adalah sesuatu yang baik. Pada karakter Orang Melayu yang terbuka dan merangkul pendatang merupakan sesuatu yang baik karena sesuai dengan nilai-nilai keislaman. Selanjutnya stereotip negatif pemalas dan tidak suka bekerja keras yang disematkan pada Orang Melayu diluruskan dengan menggambarkan bahwa wilayah Riau yang subur turut mempengaruhi cara Orang Melayu dalam mencari rezeki. Dalam pandangan masyarakat Melayu, rezeki lebih dilihat dari sudut berkahnya, bukan banyaknya. Terakhir, karakter yang disematkan pada Orang Melayu adalah tidak menjauhi konflik. Penyematan tersebut dianggap salah karena sebenarnya masyarakat Melayu tidak menghindari konflik melainkan menghindari perselisihan. Perselisihan dianggap sesuatu yang tidak membangun oleh karenanya dihindari. Bentuk menghindari perselisihan bisa dilakukan dengan cara musyawarah/berunding, atau pergi untuk sementara. Menurut Hamidy (Oktober, 2017) menghindari perselisihan merupakan bagian dari menjaga silaturahmi sesama Orang Melayu, oleh karenanya hal tersebut justru harus dipertahankan karena sesuai ajaran Islam.

Proses merekonstruksi dan meredefinisi identitas Orang Melayu di Pekanbaru Riau merupakan sebuah usaha dari para elit Riau untuk menampilkan wajah Melayu yang baru. Perubahan pascareformasi yang memberikan ruang yang luas bagi masyarakat lokal untuk tampil dalam posisiposisi strategis menjadi salah satu faktor untuk 
melawan stereotip negatif yang dianggap merugikan. Kesadaran akan pentingnya citra positif pada karakter Orang Melayu memunculkan bantahan terhadap stereotip negatif yang berkembang di masyarakat, baik yang disematkan pendatang maupun yang diakui oleh Orang Melayu itu sendiri. Dialektika di antara Orang Melayu itu mendorong pengentalan identitas yang mengarah kepada karakter yang lebih positif.

Dalam kerangka konstruksi identitas tindakan yang dilakukan Orang Melayu juga dapat dipahami sebagai upaya untuk memperbaiki citra Orang Melayu Riau. Kondisi ini didorong oleh adanya pelabelan karakter Orang Melayu yang berkonotasi negatif yang hidup dan berkembang di masyarakat Pekanbaru. Peneliti mendapatkan pandangan dari partisipan bahwa stereotype tentang Orang Melayu pemalas, tidak suka bekerja keras dan menghindari konflik merupakan bentuk ketidaktahuan pendatang terhadap Orang Melayu. Pandangan partisipan tersebut sejalan dengan kajian Susanti (2014, p. 227) yang menyatakan bahwa sebenarnya Orang Melayu justru dikenal dengan keutamaan budi dan bahasa yang menunjukan sopan-santun dan peradaban yang tinggi.

Pelekatan stereotype untuk memberikan identitas kepada kelompok/etnik tertentu dapat dipahami dari kajian yang dilakukan oleh Romli (2015, p. 10) yang menyatakan bahwa identitas selain ditentukan oleh dirinya sendiri, juga diberikan (dijuluki) oleh orang lain (baik atas persetujuan ataupun tidak). Pandangan Romli sesuai dengan kaca mata Berger dan Luckmann
(Romli, 2015, p. 10) yang menyatakan bahwa identitas merupakan suatu unsur dari kenyataan subjektif yang selalu berhubungan secara dialektif dengan masyarakat. Pelekatan stereotype negatif oleh kelompok lain dan menjadi identitas Orang Melayu merupakan bentuk dari penjelasan di atas.

Stereotype negatif yang dilekatkan ini berdasarkan temuan penelitian membuat kedudukan Orang Melayu menjadi lemah ketika dihadapkan dengan pendatang. Situasi ini dianggap tidak menguntungkan ketika era reformasi dengan otonomi dan sistem pemilihan langsung memberikan kesempatan pada Orang Melayu untuk menunjukan eksistensi. Upaya menunjukan eksistensi tersebut salahsatunya dilakukan dengan cara melawan stereotype negatif sekaligus merekonstruksi identitas. Rekonstruksi identitas dianggap perlu dilakukan karena identitas yang dilekatkan dianggap merugikan. Apa yang dilakukan Orang Melayu sejalan dengan penelitian Rozi (2013, p. 217) yang menyatakan bahwa identitas yang tidak menguntungkan yang selama ini "dilekatkan" kepada suatu etnik akan menimbulkan gugatan dari mereka yang merasa dirugikan. Gugatan tersebut muncul pada saat reformasi memberi ruang komunikasi kepada Orang Melayu untuk mendefinisikan ulang stereotype negatif yang dilekatkan pada mereka.

Stereotif bahwa Orang Melayu pemalas, tidak suka bekerja keras, menghindari konflik dan mudah dimanfaatkan telah menempatkan posisi Orang Melayu menjadi lemah ketika dihadapkan dengan pendatang. Pandangan tersebut diubah dengan meluruskan bahwa stereotype negatif 
tersebut lahir karena ketidakpahaman pendatang terhadap kehidupan Orang Melayu.

"Orang Melayu itu bukan pemalas, tapi cukup dengan yang telah didapat. Orang Melayu tidak rakus dalam mengeksploitasi alam (Darmawi, September 2017).

Upaya rekonstruksi identitas Melayu tidak berfokus pada perilaku Orang Melayu namun pada makna yang berkembang mengikutinya. Pandangan negatif terhadap karakter Orang Melayu diluruskan dengan memberikan pandangan lain yang lebih positif. Selanjutnya stereotype tentang Orang Melayu mudah dimanfaatkan juga memberikan kesadaran bahwa keterbukaan mereka selama ini sering disalahgunakan yang pada akhirnya melahirkan kewaspadaan.

"Orang Melayu harus menyadari bahwa zaman telah berubah. Dahulu mungkin manusia masih sedikit yang jahat. Namun saat ini sudah seharusnya ada kewaspadaan terhadap kehadiran orang asing di sekitar kita. Sebab tidak semuanya baik. Kewaspadaan tidak harus mengubah sifat terbuka Orang Melayu, hanya berhati-hati saja" (Sabli, Juli 2017).

Orang Melayu menyadari bahwa ruang komunikasi yang terbuka di era reformasi Reformasi tidak dapat dimanfaatkan secara maksimal ketika citra Orang Melayu berkonotasi negatif. Apalagi di era pascareformasi tuntutan Orang Melayu cukup besar berkenaan dengan tuntutan previlesse sebagai tuan rumah dan tuntutan pembagian sumber daya alam kepada perusahaan-perusahaan besar di Riau.
Identitas Orang Melayu didefinisikan melalui stereotip-stereotip yang hidup dan berkembang di masyarakat tentang perilaku dan karakter Orang Melayu dalam kehidupan seharihari. Stereotip yang berkonotasi negatif tersebut pada pascareformasi mengalami counter statemen dari Orang Melayu karena dianggap sebagai bentuk ketidaktahuan orang lain terhadap kedalaman cara berpikir, bersikap dan berperilaku Orang Melayu. Upaya tokoh Melayu untuk mengcounter stereotip negatif yang dilekatkan pada etniknya merupakan usaha untuk meningkatkan status etnik yang lebih positif. Upaya meningkatkan status etnik tersebut melibatkan perbandingan antara Orang Melayu dengan pendatang. Kondisi tersebut membuka jalan bagi lahirnya politik identitas. Adanya politik identitas pada akhirnya digunakan untuk melakukan perjuangan mengubah sistem sosial, politik, dan ekonomi yang tidak memberikan keuntungan bagi eksistensi etnik Melayu.

\section{DAFTAR PUSTAKA}

Andriana, N. 2011. Hegemoni Ideologi dalam Konstruksi Identitas Budaya Masyarakat Melayu Riau pada Desain Arsitektur. Widyariset, 14 No.1, 113-122.

Creswell, J. W. 2014. Penelitian Kualitatif \& Desain Riset; Memilih di Antara Lima Pendekatan (3rd ed.). Yogyakarta: Pustaka Pelajar.

Dahlan, S. 2004. Budaya Melayu Riau Pada Era Globalisasi. Ilmu Budaya, 1(1), 11-19.

Haboddin, M. 2012. Menguatnya Politik Identitas di Ranah Lokal. Studi Pemerintahan, 3 No.1(2003), 116-134. Retrieved from http://dx.doi.org/10.18196/jgp.2012.0007

\section{PENUTUP}


Hasbullah dan Jamaluddin. 2013. Pengrajin Songket di Bukit Batu Kabupaten Bengkalis ). Sosial Budaya, Vol. 10 No, 113.

Lampe, I., \& Anriani, H. B. 2017. Stereotipe, Prasangka dan Dinamika Antaretnik. Penelitian Pers Dan Komunikasi Pembangunan, 20(1), 17-32.

Muchtar, K., Koswara, I., Setiaman, A., 2016, KOMUNIKASI ANTAR BUDAYA DALAM PERSPEKTIF ANTROPOLOGI, Jurnal Manajemen Komunikasi Vol 1 No 1, doi

http://dx.doi.org/10.24198/jmk.v1i1.10064

Romli, H. K. 2015. Akulturasi dan Asimilasi dalam Konteks Interaksi Antaretnik. Ijtimaiyya, 8(1), 1-13. Retrieved from https://media.neliti.com/media/publication s/69473-ID-diskursus-pemberdayaanmasyarakat.pdf

Rozi, S. 2009. Nasionalisme, Demokratisasi, dan Sentimen Primordialisme di Indonesia: Problematika Identitas Keetnisan versus Keindonesiaan pada Studi Kasus Aceh, Papua, Bali dan Riau. Jurnal Penelitian Politik, 06(1), 75-84.

Rozi, S. 2013. Konstruksi Identitas Agama Dan Budaya Etnis Minangkabau Di Daerah Perbatasan: Perubahan Identitas Dalam Interaksi Antaretnis Di Rao Kabupaten Pasaman Sumatera Barat. Jurnal Masyarakat Indonesia, 39(1), 215-245.

Setiawan, I., Tallapessy, A., \& Subaharianto, A. 2015. Politik Identitas Etnis Pasca Reformasi: Studi Kasus pada Komunitas Tengger dan using. Jember.

Suciati, R., \& Agung, I. M. 2017. Perbedaan Ekspresi Emosi pada orang Batak, Jawa, Melayu dan Minangkabau. Jurnal Psikologi, 12(2), 99-108. https://doi.org/10.24014/jp.v12i2.3236

Susanti, E. 2014. Budaya Malu Cerminan bagi Perempuan Melayu. Sosial Budaya: Media
Komunikasi Ilmu-Ilmu Sosial Dan Budaya, 11(02), 226-236. 